Article

\title{
Market Reaction to Other Comprehensive Income
}

\author{
HeeJin Park \\ Division of Accounting/Tax and Management Information Systems, Kyonggi University, \\ 154-42 Gwanggyosan-ro, Yeongtong-gu, Suwon-si, Gyeonggi-do 16227, Korea; hjpark00@kgu.ac.kr
}

Received: 30 April 2018; Accepted: 1 June 2018; Published: 1 June 2018

\begin{abstract}
The comprehensive income statement was adopted as the standard type of financial statement in 2011, and other comprehensive income (OCI) was included in the text of the financial statements. While OCI (unrealized income) is less sustainable than net income, it can help to assess a firm's value. Therefore, testing the usefulness of $O C I$ is important in analyzing whether persistence of earning information affects a firm's value. The text of the financial statements enables market participants to access not only the realized net income (operating income, non-operating income), but also information on comprehensive income, which has not yet been realized. Although levels of realized and unrealized income indicate an increase in net worth, changes in realized and unrealized income differ in terms of uncertainty; it is, therefore, more important for market participants to judge information's usefulness. This study examines whether $O C I$ increases earnings response coefficients (ERC). We analyzed the information content of $O C I$ before and after international financial reporting standards (IFRS) to verify whether the information content varies as the format of OCI reporting changes from a footnote to the main text of the financial statement. In addition, we analyzed dividing $O C I$ into positive $O C I$ and negative $O C I$. The analysis showed that under the condition in which the realized income is constant, $O C I$ (which is unrealized earnings) has additional information effects. This means that differences might be observed in the decision-making process depending on whether or not the $O C I$ information is used.
\end{abstract}

Keywords: other comprehensive income; earnings response coefficient; earning's sustainability; international financial reporting standards (IFRS)

\section{Introduction}

The argument about which type of earnings reported in the financial statements will provide the most useful information for accounting is a constant topic of debate in the study of the usefulness of accounting information.

Dhaliwal et al. (1999) [1] analyzed the relationship between net income, total comprehensive income, and stock returns using U.S. data, and found no evidence that the explanatory power of total comprehensive income was higher than that of net income. Devalle et al. (2012) [2] analyzed the value relevance of net income and total comprehensive income in the period after the introduction of IFRS in the capital market of five European countries (Germany, Spain, the UK, Italy, and France). Devalle et al. (2012) [2] did not find evidence that total comprehensive income is more relevant than net income. On the other hand, Kanagaretnam et al. (2009) [3] analyzed the incremental value relevance of total comprehensive income using Canadian data and found that the total comprehensive income explained the stock price and return better than the net income. As such, previous studies comparing the value of net income with the value of total comprehensive income report mixed results.

In a previous study in Korea, in which the value relevance of other comprehensive income (OCI) items was analyzed using Ohlson's (1995) residual income valuation model, OCI items showed significant explanatory power on stock prices and returns (Choi and Ahn 2002 [4]; Song et al. 
2005 [5]). These studies generally accept the value relevance of other comprehensive income, but differ considerably in the usefulness of OCI reporting methods. Song et al. (2005) [5] argued that it would be more appropriate to disclose other comprehensive income as a note in the statement of changes in stockholders' equity rather than expanding it or applying it directly to the separate comprehensive income statement.

The most significant difference between net income and total comprehensive income is the recognition of other comprehensive income, so it is possible to verify the information content of $O C I$ while also verifying the usefulness of fair value assessment. Total comprehensive income is the net change in equity for a period not including any owner contributions or distributions. In other words, it includes all revenues, gains, expenses, and losses incurred during a period as well as the unrealized gains and losses during an accounting period. Other comprehensive income is the unrealized gain or loss resulting from fluctuation in the value of the assets or liabilities held. The "conceptual framework for financial reporting" established by the International Accounting Standards Board (IASB) stipulated that the total comprehensive income should be presented in the comprehensive income statement as a separate factor including both the net income and the OCI. In May 2010, the IASB also published its revised exposure draft plan to prepare a comprehensive income statement by classifying other comprehensive gains and losses into those that were reclassified to profit or loss during the subsequent periods into items that were not reclassified.

This amendment adopts the IASB standard that profit information from an all-inclusive concept is more useful for economic decision-making by market participants than the current operation performance concept. Given that OCI consists primarily of items related to the fair value assessment of assets and liabilities, the IASB suggests that, rather than the reliability of historical costs, the relevance of fair value is considered to be a more important qualitative characteristic. According to the 2011 Korean International Financial Reporting Standards (K-IFRS) conceptual report, relevant financial information can make a difference in decisions whether it has a predictive value or confirmatory value or both. Financial information has predictive value if it can be used as an input for the processes employed by users to predict future outcomes. Financial information has confirmatory value if it provides feedback about, confirms, or changes previous evaluations. The predictive value and confirmatory value of financial information are interrelated. Information that has a predictive value often also has a confirmatory value. Analysis of how information users evaluate OCI information in the capital market can be an important basis for future policy-making.

Of the earnings information reported in the financial statements, $\mathrm{OCI}$ information has more relevance than earnings reported based on historical cost, since it is reported earnings through fair value measurement, although it is unrealized income. Relevant financial information can make a difference in the decisions made by users. In general, if the information provided has a predictive value, confirmation value, and materiality, it is said to be relevant information. If unrealized income has relevance, it will show an additional earnings response coefficient compared to realized income. However, no studies, comparing the magnitude of the information content of OCI with realized income, have been conducted. Therefore, this study examines whether $\mathrm{OCI}$ increases earnings response coefficients $(E R C)$.

We analyzed the information content of OCI before and after IFRS to assess whether the information content varies as the format of $O C I$ reporting changes from a footnote to the main text of the financial statement. In addition, we analyzed dividing $O C I$ into positive $O C I$ and negative OCI. According to the empirical analysis, the other comprehensive income has additional information content under the condition that the realized income is constant. This implies that if there are market participants using $O C I$ information in the same market and market participants who do not use $O C I$ information, there may be differences in decision-making between these two parties, as well as additional information content of other comprehensive income. This means that the $O C I$ is relevant information. The effects of OCI since the IFRS was introduced have been found to be greater than the earlier period, meaning that the disclosure of the text of the comprehensive income statement is 
more effective than the disclosure of the footnote. In addition, the information on other comprehensive losses has been found to be greater than the information on other comprehensive gains. Even if $O C I$ is a potential earning, the same amount of loss and profit suggests that the information user's response to unrealized losses is greater than the information user's response to unrealized profits.

The content of the remainder of this study is as follows. Section 2 reviews the previous studies and provide the research hypotheses. Section 3 describes the research design and the sample selection. Section 4 reports the results of an empirical analysis, and Section 5 presents the conclusions.

\section{Literature Review and Research Hypotheses}

\subsection{Other Comprehensive Income}

Studies that analyze the information content of $O C I$ are divided into studies that analyze the usefulness of the report form of the comprehensive income statement and studies that analyze the value relevance of other comprehensive income.

Hirst and Hopkins (1998) [6], Maines and McDaniel (2000) [7] and Davis-Friday et al. (2004) [8] studied the reporting form of the comprehensive income statement. Hirst and Hopkins (1998) [6] conducted an experiment with 96 financial analysts with more than 16 years of practical experience to determine whether the accounting information reporting method had an effect on the detection of earnings management. The analysis showed that financial analysts are aware of a firm's earnings management when $O C I$ is reported in the statement of comprehensive income rather than in the statement of changes in equity. Hunton et al. (2006) [9] found that managers are less likely to engage in earnings management when comprehensive income is presented in a statement.

Maines and McDaniel (2000) [7] conducted an empirical study on MBA students to analyze whether there is a difference in general investor decision-making between investors according to the reporting format of the OCI information. Maines and McDaniel (2000) [7] assessed whether there is a difference in the information on comprehensive income felt by investors, specifically when providing information on the volatility of available-for-sale securities valuation gains and loss in the method of reporting comprehensive income statement as compared to the method of adjusting OCI directly to equity. The analysis showed that MBA students appropriately reflect the volatility of the comprehensive income when they provide information in a separate comprehensive income statement. Also, Davis-Friday et al. (2004) [8] analyzed whether reliability was affected by the differences in reporting methods on the allowance for severance liability. The analysis showed that the information users more readily believed in recognizing an allowance for severance liability when it is reported in the text of the financial statements rather than in a footnote.

Some researchers support the view that the accounting adjustments contained in $O C I$ have caused incremental $O C I$ volatility to be viewed as "noise" rather than useful for investors' decision-making (Dhaliwal et al. 1999 [1]; Yen et al. 2007 [10]; Jones and Smith 2011 [11]). Other research provides theoretical support for OCI's usefulness (Chambers et al. 2007 [12]; Goncharov and Hodgson [13]; Black 2016 [14]).

Dahaliwal et al. (1999) [1], Cahan et al. (2000) [15], and Biddle and Choi (2006) [16] studied the value relevance of other comprehensive income. Dhaliwal et al. (1999) [1] analyzed the relationship between net income, comprehensive income, and stock returns using data from 1994 and 1995, before the implementation of SFAS No. 130. The analysis found no evidence to suggest that the comprehensive income on stock returns explanatory power was higher than the current net income. In addition, a study by Cahan et al. (2000) [15] of New Zealand companies found that the total comprehensive income was more value-related than net income, while individual items of $O C I$ did not have any additional value or relevance. Jones and Smith (2011) [11] found that the earnings persistence of $O C I$ has a negative value. The evidence indicates that comprehensive income and $O C I$ are less predictable than net income. 
Biddle and Choi (2006) [16] criticized the study by Dhaliwal et al. (1999) [1] for its use of the relative value relevance analysis method in analyzing the usefulness of OCI. Instead, Biddle and Choi (2006) [16] analyzed the usefulness of $O C I$ using the incremental value relevance analysis method. Dhaliwal et al. (1999) [1] did not find comprehensive income useful when using the relative value relevance analysis method, but used the incremental value relevance analysis method to analyze the relationship between the total gross income and the constituent items. Goncharov and Hodgson (2011) [13] found that OCI and comprehensive income are value-relevant for changes in analysts' price targets. Consequently, $O C I$ items, in addition to net income, showed additional usefulness. As demonstrated above, the prior studies on the value relevance implications of $O C I$ show conflicting results.

Extant studies have examined presentation formats of "Other Comprehensive Income" after Accounting Standards Update (ASU) 2011-05. ASU 2011-05 eliminated the option of presenting OCI in the statement of changes in stockholders' equity. Veltri and Ferraro (2018) [17] examined the incremental $O C I$ value relevance in the Italian post-IAS1 environment, using a regression model that took into consideration the outcome of previous research. The results showed that OCI numbers are not incrementally value-relevant within the Italian context. Shi et al. (2017) [18] examined the relationship between the enhanced disclosure of other comprehensive income and information usefulness. The results showed that ASU 2011-05 is found to significantly increase the ability of net income to influence stock prices. As $\mathrm{OCI}$ and net income are intertwined, a more salient presentation of $O C I$ enables investors to better interpret earnings.

\subsection{Hypotheses}

The study of the information content of $O C I$ has been a major concern in determining the analysis of whether earning information, such as net income and total comprehensive income, is useful for accounting information users. Scholars who object to reporting $O C I$ in the text of financial statements argue that other comprehensive income items are likely to have a greater transitory earning and provide a forecasting error to reported earnings. They also assert that $O C I$ is mainly unrealized income and therefore can be affected by macroeconomic variables such as inflation and economic fluctuations (Black 1993 [19]; Skinner 1999 [20]; Barker 2004 [21]; Chambers et al. 2007 [12]; Khan and Bradbury 2014 [22]; Schaberl and Victoravich 2015 [23]). On the other hand, scholars who agree to reporting $O C I$ in the text of the financial statements argue that total comprehensive income corresponds to the earnings concept that meets the Ohlson (1995) [24] clean surplus relation compared to the net income. Clean surplus relation means that all changes in shareholder equity that do not result from transactions with shareholders (dividends, share repurchases, share offerings, etc.) are reflected in the income statement. On the other hand, Dirty surplus accounting occurs when some items (notably foreign currency translation adjustments, certain pension liability adjustments, etc.) are adjusted from shareholder equity without passing through the income statement. In order to adjust the income statement to reflect a clean surplus, an investor can replace "net income" with "total comprehensive income". The basic difference is that under clean surplus, all charges and credits go through the income statement; there are no items that go directly into or out of retained earnings. Additionally, in a compensation system based on total comprehensive income, incentives for a manager's earnings management do not exist because the manager considers all factors that affect a firm's value (Robinson 1991 [25]; Beresford et al. 1996 [26] Kim 2017 [27]; Shi et al. 2017 [18]).

As a result of the controversy over the usefulness of $O C I$, the recognition of $O C I$ and reporting methods has been constantly changing. However, the comprehensive income statement has been adopted as the financial statement since 2011, and OCI was included in the text of the financial statements. The text of the financial statements enables market participants to access not only the realized net income (operating income, non-operating income), but also information on comprehensive income that is not yet realized. 
Although levels of realized and unrealized income indicate an increase in net worth, changes in realized and unrealized income differ in terms of uncertainty; it is therefore more important for market participants to judge information's usefulness.

The previous studies mainly used Ohlson's (1995) model to analyze the information usefulness of OCI (Dhaliwal et al. 1999 [1]; Kanagaretnam et al. 2009 [2]). However, it is more appropriate to use the ERC model, which shows the stock price response when the unexpected earning increases, in order to determine the usefulness of the unrealized income information, the $O C I$, in comparison with the realized income. While OCI reported in the financial statements is unrealized income, it has more relevance than the realized income reported based on historical cost since it is the earnings reported through fair value valuation. If unrealized income is relevant and information users utilize the earnings information in the comprehensive income statement, the ERC of the unrealized income will appear in the market along with the ERC of the realized income. Therefore, Hypothesis 1 was set as follows.

Hypothesis 1 (H1). Under the condition that the realized income is constant, OCI will have additional information value.

Because OCI reported in the financial statements corresponds to unrealized income, there may be differences in how investors interpret and use the same information. According to the prospect theory, the value function has a more dramatic slope in the case of loss compared to the gain of the same amount (Kahneman and Tversky 1979 [28]). The value function of prospect theory generally appears as a concave form in the profit environment and a convex form in the loss environment. The slope of the value function is steeper in the loss environment than in the profit environment, and it can be seen that a larger inefficiency appears at the same amount of loss than at the same amount of profit. If the prospect theory is established not only for realized income but also for unrealized income, the information value of the same negative $O C I$ in the capital market will be greater than that of the same positive $O C I$. By verifying the information content of the sign (plus or minus) on incremental $O C I$, we can identify how investors perceive $O C I$.

Even if $O C I$ is a potential earning, it can be expected that if the same amount of loss and gain occur, the information user's response to unrealized loss will be greater than the information user's response to unrealized gain. Therefore, Hypothesis 2 was established as follows.

Hypothesis 2 (H2). Under the condition that the realized income is constant, the information content of a firm with negative OCI will be greater than the information content of a firm with positive OCI.

Korea adopted the Korea International Financial Reporting Standards (K-IFRS) in 2011. Accordingly, the reporting format of $O C I$ has been changed from the footnote disclosure to the text of the comprehensive income statement. This implies an increase in availability and accessibility of $O C I$ information; the information is likely to be affected as the reporting format of the $O C I$ changes from the footnote to the text of the comprehensive income statement.

Efficient market theory states that changes in the accounting principles do not alter the stock price unless the future cash flow of the firm is impacted; thus, a difference in the reporting method of the OCI does not create a difference in the share price itself. Therefore, it should not have affected stock prices when $O C I$ information changed from the footnote to the text of the comprehensive income statement as of 2011.

However, Hirst and Hopkins (1998) [6] and Davis-Friday et al. (2004) [8] concluded that differences in information reporting methods had a psychological effect on investor decision-making and resulted in different value-relevance. In a case where the availability and accessibility of the information are limited due to practical constraints, the information user may recognize the information in the text as being more important, and may not be able to fully review the content of the footnote. Hirst and Hopkins (1998) [6] conducted an experiment with 96 financial analysts with more than 16 years of 
practical experience to determine whether the reporting method used had an effect on detection of earnings management. The analysis showed that financial analysts are aware of a firm's earnings management when other comprehensive income is reported in the statement of comprehensive income rather than in the statement of changes in equity. Also, Davis-Friday et al. (2004) [8] analyzed whether differences in reporting methods for allowance for severance liability affected reliability. The analysis showed that information users more readily recognized allowance for severance liability reported in the text of the financial statements than in a footnote. In this study, we expect that the effects of changes in the reporting format of $\mathrm{OCI}$ on the capital market will differ. Therefore, Hypothesis 3 was established as follows.

Hypothesis 3 (H3). Under the condition that the realized income is constant, the information content of OCI will be greater in subsequent periods than in the period prior to K-IFRS adoption.

\section{Research Design and Sample Selection}

\subsection{Empirical Models}

In previous studies on the information content of $O C I$, the value relevance of $O C I$ items was analyzed using Ohlson's (1995) residual income valuation model. In this study, we analyzed the information content of OCI using the ERC model. Since Ball and Brown (1968) [29], many financial accounting researchers have examined the $E R C$, which is defined as the effect of a $\$ 1$ change in earnings on the dollar stock returns. The $E R C$ is the slope coefficient for the regression of returns for the change in earnings.

In this study, Ordinary Least Square(OLS) regression analysis was performed to analyze the information content of OCI. The OLS regression analysis was conducted in this study as well as in previous studies analyzing information content. (Kormendi and Lipe 1987 [30]; Easton and Zmijewski 1989 [31]; Collins and Kothari 1989 [32]; Imhoff and Lobo 1992 [33]; Basu 1997 [34]; Mian and Sankaraguruswamy 2012 [35]). We analyzed the information usefulness of OCI, which is the unrealized income, by including the realized income $(O I, N O I)$. The text of the financial statements enables market participants to access not only the realized net income (operating income, non-operating income), but also information on comprehensive income, which has not yet been realized. In this regression, the main variable of interest is $\triangle O C I$ after controlling for $\triangle O I$ and $\triangle N O I$. In order to analyze the additional information content of $O C I$ under the condition that realized income is constant, Equation (1) is set as follows. The control variables include firm size, debt ratio, operating cash flow, and loss. We included $L E V$ as a control variable to reflect the result of a previous study that showed low leveraged firms have a larger ERC than high leveraged firms (Dahliwal et al. 1991 [36]). In addition, we added SIZE and OCF into the model to control for the effects of firm size and performance on the ERC (Collins and Kothari 1989 [18]).

If $O C I$ is realized, it is non-operating income rather than operating income. Thus, the net income was included in the model, and was divided into operating income and non-operating income. In addition, to analyze the information content of $O C I$, a change in the $O C I$ variable $(\triangle O C I)$ was measured using the footnote or the text of the comprehensive income statement. In previous studies, other comprehensive income variables were measured by standardizing the total amount of gains (losses) on valuation of available-for-sale financial assets, gains (losses) on overseas operations translation, and gains (losses) on valuation of derivative instruments, which are mainly shown as capital adjustment items in the statement of financial position. This study used other comprehensive income information reported in the statement of comprehensive income. Assuming that coefficient $\beta_{3}$ 
in Equation (1) has a significantly positive value, Hypothesis 1 supports that $O C I$ will have additional information content if the realized income is constant.

$$
\begin{gathered}
\text { RET }_{i t}=\beta_{0}+\beta_{1} \Delta O I_{i t}+\beta_{2} \Delta N O I_{i t}+\beta_{3} \Delta O C I_{i t}+\beta_{4} S I Z E_{i t}+\beta_{5} L E V_{i t} \\
+\beta_{6} O C F_{i t}+\beta_{7} L^{O O S S} S_{i t}+\sum \beta_{m} I N D+\varepsilon
\end{gathered}
$$

where RET represents the market-adjusted stock return that equal the buy-and-hold stock returns from the second quarter of year $t$ to the first quarter of year $t+1$, minus the market index. A listed company must submit a business report within 90 days of the end of each accounting period, so the actual availability of accounting information for the 31 December closing corporation is from 1 April. $\triangle O I$ is changes in operating income scaled by lagged total assets. $\triangle N O I$ is changes in non-operating income scaled by lagged total assets. $\triangle O C I$ is changes in other comprehensive income divided by lagged total assets. $O C I$ is unrealized gains and losses related to changes in the fair values of derivative contracts classified as cash flow hedges plus unrealized gains and loss related to changes in fair values of investment securities classified as available for sale. SIZE is computed as the natural logarithm of the total assets of the firm. $L E V$ is defined as liabilities over equity. $O C F$ is the operating cash flow scaled by lagged total assets. LOSS is a dummy variable equal to 1 if the firm reported a loss in year $t$, or 0 otherwise. We add industry dummies in order to address for the cross-sectional fixed effects. We also adjust the $t$-statistics by using standard errors clustered on firm and year, as in Gow et al. (2010) [37].

Equation (2) is a model designed to test Hypothesis 2 that suggests that the information content of a firm with negative $O C I$ will be greater than the information content of a firm with positive $O C I$ under the condition that the realized income is constant. According to the prospect theory, the information user's response to unrealized loss is greater than the information user's response to unrealized gain. Therefore, Hypothesis 2 is supported if the coefficient $\beta_{9}$ on the interaction term $\left(\triangle O C I \times N E G_{-} O C I\right)$ shows a significantly positive value.

$$
\begin{aligned}
R E T_{i t}= & \beta_{0}+\beta_{1} \Delta O I_{i t}+\beta_{2} \Delta N O I_{i t}+\beta_{3} \Delta O C I_{i t}+\beta_{4} N E G_{-} O I_{i t} \\
& +\beta_{5} N E G_{-} N O I_{i t}+\beta_{6} N E G_{-} O C I_{i t}+\beta_{7} \Delta O I_{i t} \times N E G_{-} O I_{i t} \\
& +\beta_{8} \Delta N O I_{i t} \times N E G_{-} N O I_{i t}+\beta_{9} \Delta O C I_{i t} \times N E G_{-} O C I_{i t} \\
& +\beta_{10} S I Z E_{i t}+\beta_{11} L E V_{i t}+\beta_{12} O C F_{i t}+\beta_{13} L O S S_{i t}+\sum \beta_{m} I N D+\varepsilon,
\end{aligned}
$$

where NEG_OI is an indicator variable equal to 1 if the firm reported a negative operating income in year $t$, or 0 otherwise. NEG_NOI is an indicator variable equal to 1 if the firm reported a negative non-operating income in year $t$, or 0 otherwise. Neg_OCI is an indicator variable equal to 1 if the firm reported a negative other comprehensive income in year $t$, or 0 otherwise. All other variables are as defined in Equation (1).

As all listed firms in Korea must prepare their financial statements in accordance with IFRS as of 1 January 2011, the reporting format of OCI has been changed from the footnote disclosure to the text of the comprehensive income statement. We divided sample into the pre-IFRS period, 2007-2010, and the post-IFRS period, 2011-2014. Equation (3) is a model designed to verify Hypothesis 3, which suggests that the information content of $O C I$ will be greater in subsequent periods than the period prior to K-IFRS adoption under the condition that the realized income is constant.

Hirst and Hopkins (1998) [6] and Davis-Friday et al. (2004) [8] concluded that information users more readily believe the information displayed in the text of financial statements than in a footnote.

In other words, users may not only consider the information in the text as more important, but also may not be able to fully review the content of the footnote due to practical constraints. Therefore, if the difference in types of OCI reporting methods affects the information content of 
earnings, then the coefficient $\beta_{7}$ of the interaction term ( $\left.\triangle O C I \times I F R S\right)$ in Equation (3) can be expected to have a significantly positive value.

$$
\begin{aligned}
R E T_{i t}= & \beta_{0}+\beta_{1} \Delta O I_{i t}+\beta_{2} \Delta N O I_{i t}+\beta_{3} \Delta O C I_{i t}+\beta_{4} I F R S_{i t} \\
& +\beta_{5} \Delta O I_{i t} \times I F R S_{i t}+\beta_{6} \Delta N O I_{i t} \times I F R S_{i t}+\beta_{7} \Delta O C I_{i t} \times I F R S_{i t} \\
& +\beta_{8} S I Z E_{i t}+\beta_{9} L E V_{i t}+\beta_{10} O C F_{i t}+\beta_{11} L_{O S S}+\sum \beta_{m} I N D+\varepsilon
\end{aligned}
$$

where IFRS is an indicator variable equal to 1 for the post-IFRS period, or 0 otherwise. All of the other variables are as defined in Equation (1).

\subsection{Sample Selection}

Our sample consisted of firms listed on the Korea Stock Exchange (KSE) during the period 2007-2014. We obtained financial data from the KIS-VALUE, which provides the financial statements of all listed firms, and stock data from the Fn-Guide. For comparability, we deleted firms with non-December fiscal year-ends and all firms in which total liabilities were larger than the total assets. This screening procedure yielded a total of 2811 firm-year observations. We winsorize each of the continuous variables at the 1st and 99th percentiles to minimize the effect of outliers.

\section{Empirical Results}

\subsection{Descriptive Statistics and Correlations}

Table 1 provides descriptive statistics for the variables used in the regression analysis. The mean (median) of the market-adjusted stock return (RET) is $0.086(-0.020)$. The mean of RET was 0.086, which represents the average response to positive, negative, and no-news surprises. $\triangle O I$ indicates the unexpected operating income, which corresponds to the change in operating income from the previous year scaled by the lagged total asset. $\triangle N O I$ indicates the unexpected non-operating income, which corresponds to the change in non-operating income from the previous year scaled by the lagged total asset. $\triangle O C I$ indicates the unexpected other comprehensive income, which corresponds to the change in other comprehensive income from the previous year scaled by the lagged total asset. The means of changes in operating income $(\triangle O I)$, changes in non-operating income $(\triangle N O I)$, and changes in $O C I$ $(\triangle O C I)$ are $0.003,-0.003$, and 0.001 , respectively. The experimental variables used in the analysis were standardized by dividing them into total assets, so that the mean value of the variation is not significantly different from 0 .

The mean of the IFRS variables is 0.658 , with a total of 1,851 samples from 2011 of a total of 2,811 samples. NEG_OI, NEG_NOI, and NEG_OCI are companies with negative operating income, negative non-operating income, and negative $O C I$ variables, respectively. Of the total samples, 359 companies (12.8\%) showed a NEG_OI, 2,309 companies (82.1\%) showed a NEG_NOI, and 1,652 companies (58.8\% showed a NEG_OCI. As for the control variables, the distribution of LEV stays stable around a median value of 1.057. In addition, the mean (median) value of $O C F$, which is 0.051 (0.047), shows that the overall profitability of the sample firms is positive.

The Pearson correlations among the variables used in the main analysis are presented in Table 2. The correlation between $\triangle O C I$ and $\triangle N O I$ is negatively significant. The negative correlation between $\triangle O C I$ and $\triangle N O I$ suggests that other comprehensive income would be related to non-operating income. While the correlation between RET and control variables such as SIZE, LEV, and LOSS is positively significant, the correlation between $R E T$ and $O C F$ is negatively significant. The variance inflation factor (VIF) for independent variables is 6.225 , which is less than 10 , implying no serious multicollinearity problem. 
Table 1. Descriptive statistics $(n=2811)$.

\begin{tabular}{cccccccc}
\hline Variable & Mean & Std. & Min & p25 & Median & p75 & Max \\
\hline RET & 0.086 & 0.471 & -0.836 & -0.208 & -0.020 & 0.255 & 2.672 \\
OI & 0.052 & 0.062 & -0.202 & 0.021 & 0.046 & 0.080 & 0.299 \\
NOI & -0.022 & 0.034 & -0.260 & -0.034 & -0.019 & -0.006 & 0.137 \\
OCI & 0.004 & 0.035 & -0.104 & -0.005 & -0.001 & 0.003 & 0.361 \\
$\Delta O I$ & 0.003 & 0.049 & -0.347 & -0.017 & 0.001 & 0.022 & 0.355 \\
$\Delta$ NOI & -0.003 & 0.076 & -2.451 & -0.014 & -0.002 & 0.011 & 0.723 \\
$\Delta O C I$ & 0.001 & 0.051 & -0.409 & -0.007 & 0.000 & 0.006 & 0.436 \\
IFRS & 0.658 & 0.474 & 0 & 0 & 1 & 1 & 1 \\
NEG_OI & 0.128 & 0.334 & 0 & 0 & 0 & 0 & 1 \\
NEG_NOI & 0.821 & 0.383 & 0 & 1 & 1 & 1 & 1 \\
NEG_OCI & 0.588 & 0.492 & 0 & 0 & 1 & 1 & 1 \\
SIZE & 27.301 & 1.604 & 24.000 & 26.146 & 27.018 & 28.251 & 31.964 \\
LEV & 1.240 & 0.890 & 0.117 & 0.551 & 1.057 & 1.681 & 4.756 \\
OCF & 0.051 & 0.077 & -0.267 & 0.009 & 0.047 & 0.091 & 0.350 \\
LOSS & 0.210 & 0.408 & 0 & 0 & 0 & 0 & 1 \\
\hline
\end{tabular}

Variables definitions; RET: the buy and hold market-adjusted return for firm i over the one-year period from the second quarter of year $t$ to the first quarter of year $t+1$; OI: the operating income divided by the total assets; NOI: the non-operating income divided by the total assets; OCI: the other comprehensive income divided by the total assets; $\triangle O I$ : change in operating income $(\mathrm{OI}) ; \triangle N O I$ : change in non-operating income $(N O I) ; \triangle O C I$ : change in other comprehensive income (OCI); IFRS: 1 if reports under IFRS, or 0 otherwise; NEG_OI: one if the operating income is less than 0 , or 0 otherwise; NEG NOI: one if the non-operating income is less than 0 , or 0 otherwise; NEG_OCI: one if the other comprehensive income is less than 0, or 0 otherwise; SIZE: the natural logarithm of the total assets; LEV: the total debt divided by the net assets; OCF: cash flow from operations scaled by equity; LOSS: 1 if net income is less than 0 , or 0 otherwise.

Table 2. Correlations among the variables $(n=2811)$.

\begin{tabular}{|c|c|c|c|c|c|c|c|c|c|c|c|}
\hline & RET & $\Delta O I$ & $\triangle N O I$ & $\triangle O C I$ & IFRS & NEG_OI & NEG_NOI & NEG_OCI & SIZE & $L E V$ & OCF \\
\hline$\Delta O I$ & 0.258 & & & & & & & & & & \\
\hline$\Delta N O I$ & 0.021 & -0.148 & & & & & & & & & \\
\hline$\triangle O C I$ & 0.020 & -0.012 & -0.069 & & & & & & & & \\
\hline IFRS & 0.19 & -0.129 & 0.004 & -0.041 & & & & & & & \\
\hline NEG_OI & -0.145 & -0.287 & -0.022 & 0.040 & 0.080 & & & & & & \\
\hline NEG_NOI & -0.020 & 0.113 & -0.205 & 0.021 & 0.017 & -0.055 & & & & & \\
\hline NEG_OCI & 0.046 & -0.020 & 0.045 & -0.335 & 0.180 & -0.030 & -0.009 & & & & \\
\hline SIZE & -0.094 & -0.010 & 0.011 & -0.011 & -0.043 & -0.201 & 0.043 & 0.044 & & & \\
\hline LEV & -0.080 & -0.004 & -0.065 & 0.022 & -0.054 & 0.082 & 0.195 & 0.002 & 0.262 & & \\
\hline$O C F$ & 0.154 & 0.228 & 0.028 & -0.009 & -0.063 & -0.306 & 0.041 & 0.007 & 0.139 & -0.238 & \\
\hline LOSS & -0.168 & -0.227 & -0.126 & 0.058 & 0.072 & 0.674 & 0.108 & -0.036 & -0.158 & 0.247 & -0.344 \\
\hline
\end{tabular}

Please see Table 1 for variable definitions; coefficients shown in bold are significant at $p<0.05$ (two-tailed test).

\subsection{Regression Results}

\subsubsection{Results for the Information Content of OCI (H1)}

Table 3 presents the results of the test of our first hypothesis from the regression analysis based on Equation (1). The first column shows the information content of OCI for all firms. The second and third columns show $\triangle O C I$ among the three groups of the entire sample, based on the yearly size of $\triangle O C I$, the results of the information content of OCI in the large group, and those of the small group. The entire sample is 2811, and the samples with the largest $\triangle O C I$ and the smallest $\triangle O C I$ are 936 and 935, respectively. 
Table 3. Information content of other comprehensive income.

\begin{tabular}{|c|c|c|c|c|c|c|c|}
\hline \multirow[b]{2}{*}{ Variable } & \multirow[b]{2}{*}{ Exp. Sign } & \multicolumn{2}{|c|}{ Full Sample } & \multicolumn{2}{|c|}{ Large $\triangle O C I$} & \multicolumn{2}{|c|}{ Small $\triangle O C I$} \\
\hline & & Coeff. & $t$-Value & Coeff. & $t$-Value & Coeff. & $t$-Value \\
\hline Intercept & & 1.011 & $2.13 *$ & 0.845 & 1.48 & 1.067 & $3.24 * *$ \\
\hline$\Delta O I$ & + & 2.115 & $6.36^{* * *}$ & 2.746 & $6.84^{* * *}$ & 1.737 & $8.10^{* * *}$ \\
\hline$\triangle N O I$ & + & 0.264 & $1.98 *$ & 0.279 & $2.02 *$ & 0.289 & 1.07 \\
\hline$\triangle O C I$ & + & 0.276 & $1.95 *$ & 1.011 & $2.25 *$ & -0.225 & -0.44 \\
\hline SIZE & - & -0.035 & $-2.22 *$ & -0.029 & -1.47 & -0.04 & $-3.38^{* *}$ \\
\hline$L E V$ & - & 0.002 & 0.11 & -0.006 & -0.29 & -0.001 & -0.03 \\
\hline OCF & + & 0.509 & $3.88^{* * *}$ & 0.520 & 1.56 & 0.331 & 1.25 \\
\hline LOSS & - & -0.116 & $-4.79^{* * *}$ & -0.064 & $-2.48 * *$ & -0.135 & $-3.32 * *$ \\
\hline \multicolumn{2}{|c|}{ IND } & \multicolumn{2}{|c|}{ Include } & \multicolumn{2}{|c|}{ Include } & \multicolumn{2}{|c|}{ Include } \\
\hline \multicolumn{2}{|c|}{$F$-value } & \multicolumn{2}{|c|}{$21.93^{* * *}$} & \multicolumn{2}{|c|}{$10.18^{* * *}$} & \multicolumn{2}{|c|}{$8.26^{* * *}$} \\
\hline \multicolumn{2}{|c|}{ Adj. $R^{2}$} & \multicolumn{2}{|c|}{0.101} & \multicolumn{2}{|c|}{0.171} & \multicolumn{2}{|c|}{0.140} \\
\hline \multicolumn{2}{|c|}{$n$} & \multicolumn{2}{|c|}{2811} & \multicolumn{2}{|c|}{936} & \multicolumn{2}{|c|}{935} \\
\hline
\end{tabular}

Please see Table 1 for variable definitions; ${ }^{* * *, * * *}$ indicate significance at the $10 \%, 5 \%$, and $1 \%$ levels, respectively (two-tailed). We adjusted the $t$-statistics by using standard errors clustered on firm and year as in Gow et al. (2010).

In the entire sample, the regression coefficient of $\triangle O C I$ was 0.276 , which was a significantly positive value, as expected. Since the coefficient of $\triangle O C I$ is 0.276 , when $\triangle O C I$ increases by one unit of standard deviation from the median, $R E T$ increases by $1.41 \%(=0.276 \times 0.051)$. This result supports Hypothesis 1, which suggests that, under the condition that the realized income is constant, OCI will have additional information content. It should be noted that the regression coefficient of $\triangle O C I$ is significant in the largest group of $\triangle O C I$, while the regression coefficient of $\triangle O C I$ is not significant in the smallest group of $\triangle O C I$. This suggests that the usefulness of $O C I$ is dependent on the relative size of OCI.

Most of the control variables have a significant association with RET, especially for the strongly negative coefficients on SIZE and LOSS, and the positive coefficients on OCF. The coefficients on SIZE are significantly negative. The larger the firm, the greater the number of stakeholders, financial analysts, and investment analysts. As a result, before the earnings announcement, a lot of information about the business performance of a firm is already transferred to the capital market. The earnings information disclosed is reflected in the share price so that the information content of earnings will be lowered. Therefore, the larger the firm size, the smaller the ERC. The coefficients on $O C F$ are significantly positive. Companies with a better operating cash flow are more likely to grow. The earnings information contains useful information about the growth potential of firm. Thus, the investor's response to the earnings information of firms with large operating cash flow increases, and $E R C$ increases as the operating cash flow is better.

\subsubsection{Results for the Information Content of Positive (Negative) OCI (H2)}

Table 4 presents the empirical results for the estimations of Equation (2). In Table 4, Hypothesis 2 is supported if coefficient $\beta_{9}$ on the interaction term $\left(\triangle O C I \times N E G_{-} O C I\right)$ shows a significantly positive value. The result of the analysis shows that the regression coefficient of $\triangle O C I \times N E G \_O C I$ was 1.246 in the model excluding $\triangle O I \times N E G \_O I$ and $\triangle N O I \times N E G_{-} N O I$, and the regression coefficient of $\triangle O C I \times N E G \_O C I$ was 1.230 in the model including $\triangle O I \times N E G \_O I$ and $\triangle N O I \times N E G \_N O I$. This suggests that even if $O C I$ is a potential profit or loss, the information user's $E R C$ to unrealized losses would be greater than the information user's $E R C$ to unrealized gains if there is a loss or gain of the same amount. It is also consistent with the prospect theory, suggesting that the value function has a sharper slope. Most of the control variables have a significant association with RET, especially for the strongly negative coefficients on SIZE and LOSS, and the positive coefficients on OCF. The coefficients on SIZE are significantly negative. This is consistent with the results in Table 3. 
Table 4. Information content of positive (negative) other comprehensive income.

\begin{tabular}{|c|c|c|c|c|c|}
\hline Variable & Exp. Sign & Coeff. & $t$-Value & Coeff. & $t$-Value \\
\hline Intercept & & 0.982 & $2.03 *$ & 1.020 & $2.08 *$ \\
\hline$\Delta O I$ & + & 2.156 & $6.80^{* * *}$ & 2.590 & $5.64^{* * *}$ \\
\hline$\triangle N O I$ & + & 0.246 & 1.59 & 0.342 & 1.39 \\
\hline$\triangle O C I$ & + & 0.004 & 0.01 & -0.018 & -0.04 \\
\hline NEG_OI & $+1-$ & & & -0.067 & -1.73 \\
\hline NEG_NOI & $+1-$ & & & -0.035 & -1.31 \\
\hline NEG_OCI & + & 0.065 & $2.27 *$ & 0.065 & $2.24^{*}$ \\
\hline$\Delta O I \times \bar{N} E G \_O I$ & $+/-$ & & & -1.750 & $-3.26 * *$ \\
\hline$\triangle N O I \times N E G \_N O I$ & $+/-$ & & & -0.108 & -0.36 \\
\hline$\triangle O C I \times N E G \_O C I$ & + & 1.246 & $2.62 * *$ & 1.230 & $2.38^{*}$ \\
\hline SIZE & - & -0.035 & -2.15 * & -0.035 & -2.16 * \\
\hline$L E V$ & - & 0.001 & 0.04 & 0.001 & 0.02 \\
\hline$O C F$ & + & 0.502 & $3.97 * * *$ & 0.479 & $3.59 * *$ \\
\hline LOSS & - & -0.112 & $-4.73 * * *$ & -0.096 & $-3.49 * *$ \\
\hline$I N D$ & & \multicolumn{2}{|c|}{ Include } & \multicolumn{2}{|c|}{ Include } \\
\hline$F$-value & & \multicolumn{2}{|c|}{$20.97^{* * *}$} & \multicolumn{2}{|c|}{$18.00^{* * *}$} \\
\hline $\operatorname{Adj} . R^{2}$ & & \multicolumn{2}{|c|}{0.108} & \multicolumn{2}{|c|}{0.113} \\
\hline$n$ & & \multicolumn{2}{|c|}{2811} & \multicolumn{2}{|c|}{2811} \\
\hline
\end{tabular}

Please see Table 1 for variable definitions; $* * *, * * *$ indicate significance at the $10 \%, 5 \%$, and $1 \%$ levels, respectively (two-tailed). We adjusted the $t$-statistics by using standard errors clustered on firm and year, as in Gow et al. (2010).

\subsubsection{Results for the Information Content of OCI under K-IFRS (H3)}

Table 5 presents the results for the test of our third Hypothesis from the regression analysis based on Equation (3). In Table 5, Hypothesis 3 is supported if the coefficient $\beta_{7}$ in the interaction term $(\triangle O C I \times I F R S)$ shows a significantly positive value. In the analysis, the regression coefficient of $\triangle O C I \times I F R S$ was 0.802 , which is a significantly positive value in the partial model, and the regression coefficient of $\triangle O C I \times I F R S$ was 0.786 in the full model. This implies that the information content of $O C I$ appears to be greater in the post-IFRS period. It suggests that the information content of other comprehensive income has increased due to the increase in availability and accessibility to $O C I$ information in the post-IFRS period. Most of the control variables have a significant association with $R E T$, especially for the strongly negative coefficients on SIZE and LOSS, and the positive coefficients on OCF. The coefficients on SIZE are significantly negative. This is consistent with the results in Table 3.

Table 5. Information content of other comprehensive income under K-IFRS.

\begin{tabular}{|c|c|c|c|c|c|}
\hline Variable & Exp. Sign & Coeff. & $t$-Value & Coeff. & $t$-Value \\
\hline Intercept & & 0.750 & $4.79 * * *$ & 0.759 & $4.85^{* * *}$ \\
\hline$\Delta O I$ & + & 2.386 & $13.32 * * *$ & 2.065 & $7.92 * * *$ \\
\hline$\triangle N O I$ & + & 0.236 & $2.14^{* *}$ & 0.782 & $2.97^{* * *}$ \\
\hline$\triangle O C I$ & + & 0.280 & 1.53 & 0.311 & $1.70 *$ \\
\hline IFRS & $+/-$ & 0.359 & $11.13^{* * *}$ & 0.339 & $10.33^{* * *}$ \\
\hline$\triangle O I \times I F R S$ & $+/-$ & & & 0.750 & $2.17 * *$ \\
\hline$\triangle N O I \times I F R S$ & $+1-$ & & & -0.664 & $-2.30^{* *}$ \\
\hline$\triangle O C I \times I F R S$ & + & 0.802 & $2.07^{* *}$ & 0.786 & $2.02 * *$ \\
\hline SIZE & - & -0.034 & $-6.09 * * *$ & -0.034 & $-6.02 * * *$ \\
\hline$L E V$ & - & 0.013 & 1.20 & 0.011 & 1.09 \\
\hline OCF & + & 0.543 & $4.47^{* * *}$ & 0.522 & $4.30^{* * *}$ \\
\hline LOSS & - & -0.130 & $-5.68^{* * *}$ & -0.123 & $-5.37^{* * *}$ \\
\hline$I N D$ & & \multicolumn{2}{|c|}{ Include } & \multicolumn{2}{|c|}{ Include } \\
\hline$F$-value & & \multicolumn{2}{|c|}{$25.50^{* * *}$} & \multicolumn{2}{|c|}{$23.99 * * *$} \\
\hline $\operatorname{Adj} . R^{2}$ & & \multicolumn{2}{|c|}{0.161} & \multicolumn{2}{|c|}{0.165} \\
\hline$n$ & & \multicolumn{2}{|c|}{2811} & \multicolumn{2}{|c|}{2811} \\
\hline
\end{tabular}

Please see Table 1 for variable definitions; ${ }^{*, * *, * * *}$ indicate significance at the $10 \%, 5 \%$, and $1 \%$ levels, respectively (two-tailed). We adjusted the $t$-statistics by using standard errors clustered on firm and year, as in Gow et al. (2010). 


\section{Conclusions}

Despite the theoretical debate about the usefulness of $O C I$ information, the "conceptual framework for financial reporting" established in 2010 by the IASB provides the other comprehensive income separately to the statement of comprehensive income. In May 2010, the IASB issued a revised exposure draft, which led to the compilation of a comprehensive income statement by separating $O C I$ into items reclassified according to profit or loss in subsequent periods and items not reclassified.

This amendment adopts the IASB standard, stating that earnings information from an all-inclusive concept is more useful for economic decision-making by market participants than current operating performance. Given that $O C I$ is primarily related to the fair value of an asset or a liability, the IASB suggests that the relevance of the fair value is more qualitative than the reliability of the historical cost.

In previous studies on the information content of OCI that focused on the value relevance of OCI items using Ohlson's (1995) residual income valuation model, the analysis of the capital market's response to OCI information was insufficient. In this study, we analyzed the information content of OCI using the ERC model. This study used data from the period 2007 to 2014, starting when OCI information was first disclosed as a comment, for a total of eight years. The information of $O C I$ on various aspects such as loss, post-IFRS, etc. is also analyzed.

The positive relationship between $O C I$ and RET is found in a regression setting that uses the annual excessive stock returns as the dependent variable. The test results show that OCI has significant content, even after controlling for the firm characteristics that can potentially influence the ERC. Second, we found evidence that the market response to $\triangle O C I$ is stronger for loss firms than for profit firms. This is consistent with prospect theory, suggesting that the value function has a sharper slope in the case of loss. Finally, the market response to $\triangle O C I$ is significantly higher for the post-IFRS period than for the pre-IFRS period. This suggests that the information content of other comprehensive income has increased due to the increase in availability and accessibility to $O C I$ information in the post-IFRS period. The analysis showed that under the condition in which the realized income is constant, $O C I$, which is unrealized earnings, has additional relevance. This means that differences may occur in the decision-making process depending on whether or not the $O C I$ information is used.

Conflicts of Interest: The authors declare no conflict of interest.

\section{References}

1. Dhaliwal, D.; Subramanyam, K.R.; Trezevant, R. Is comprehensive income superior to net income as a measure of firm performance. J. Account. Econ. 1999, 26, 43-67. [CrossRef]

2. Devalle, A.; Magarini, R. Assessing the value relevance of total comprehensive income under IFRS: An empirical evidence from European stock exchanges. Int. J. Account. Audit. Perform. Eval. 2012, 8, 43-68. [CrossRef]

3. Kanagaretnam, K.; Mathieu, R.; Shehata, M. Usefulness of comprehensive income reporting in Canada. J. Account. Public Policy 2009, 28, 349-365. [CrossRef]

4. Choi, W.S.; Ahn, T.S. The incremental information content of other comprehensive income. Korean Account. Rev. 2002, 27, 81-105.

5. Song, H.J.; Kim, Y.B.; Oh, O.R. A study on the validity of comprehensive income reporting. Korean Manag. Rev. 2005, 3, 245-266.

6. Hirst, D.E.; Hopkins, P.E. Comprehensive income reporting and analysts' valuation judgments. J. Account. Res. 1998, 36, 47-75. [CrossRef]

7. Maines, L.A.; McDaniel, L.S. Effect of comprehensive-income characteristics on nonprofessional investors' judgements: The role of financial-statement presentation format. Account. Rev. 2000, 75, 179-207. [CrossRef]

8. Davis-Friday, P.Y.; Liu, C.S.; Mittelstaedt, H. Recognition and disclosure reliability: Evidence from SFAS No. 106. Cont. Account. Res. 2004, 21, 399-429. [CrossRef]

9. Hunton, J.; Libby, R.; Mazza, C. Financial reporting transparency and earnings management. Account. Rev. 2006, 81, 135-157. [CrossRef] 
10. Yen, A.; Hirst, D.; Hopkins, P. A content analysis of the comprehensive income exposure draft comment letters. Res. Account. Regul. 2007, 19, 53-79. [CrossRef]

11. Jones, D.A.; Smith, K.J. Comparing the value relevance, predictive value, and persistence of other comprehensive income and special items. Account. Rev. 2011, 86, 2047-2073. [CrossRef]

12. Chambers, D.; Linsmeier, T.J.; Shakespeare, C.; Sougiannis, T. An evaluation of sfas no. 130 comprehensive income disclosures. Rev. Account. Stud. 2007, 12, 557-593. [CrossRef]

13. Goncharov, I.; Hodgson, A. Measuring and reporting income in Europe. J. Int. Account. Res. 2011, 10, 27-59. [CrossRef]

14. Black, D.E. Other comprehensive income: A review and directions for future research. Account. Financ. 2016, 56, 9-45. [CrossRef]

15. Cahan, S.; Courtenay, S.; Gronewoller, P.; Upton, D. Value relevance of mandated comprehensive income disclosures. J. Bus. Financ. Account. 2000, 27, 1273-1301. [CrossRef]

16. Biddle, G.; Choi, J. Is comprehensive income useful? J. Cont. Account. Econ. 2006, 9, 231-258. [CrossRef]

17. Veltri, S.; Ferraro, O. Does other comprehensive income matter in credit-oriented systems? Analyzing the Italian context. J. Int. Account. Audit. Tax. 2018, 30, 18-31. [CrossRef]

18. Shi, L.; Wang, P.; Zhou, N. Enhanced disclosure of other comprehensive income and increased usefulness of net income: The implications of Accounting Standards Update 2011-2005. Res. Account. Regul. 2017, 29, 139-144. [CrossRef]

19. Black, F. Choosing accounting rules. Account. Horiz. 1993, 7, 1-17.

20. Skinner, D. How well does net income measure firm performance? A discussion of two studies. J. Account. Econ. 1999, 26, 105-111. [CrossRef]

21. Barker, R. Reporting financial performance. Account. Horiz. 2004, 18, 157-172. [CrossRef]

22. Khan, S.; Bradbury, M.E. Volatility and risk relevance of comprehensive income. J. Cont. Account. Econ. 2014, 10, 76-85. [CrossRef]

23. Schaberl, P.D.; Victoravich, L.M. Reporting location and the value relevance of accounting information: The case of other comprehensive income. Adv. Account. 2015, 31, 239-246. [CrossRef]

24. Ohlson, J.A. Earnings, book values, and dividends in equity valuation. Cont. Account. Res. 1995, 11, 661-687. [CrossRef]

25. Robinson, L. The time has come to report comprehensive income. Account. Horiz. 1991, 5, 107-112.

26. Beresford, D.; Johnson, L.; Reither, C. Is a second income statement needed? J. Account. 1996, 176, 69-72.

27. Kim, J.H. Presentation formats of other comprehensive income after accounting standards update 2011-05. Res. Account. Regul. 2016, 28, 118-122. [CrossRef]

28. Kahneman, D.; Tversky, A. Prospect theory: An analysis of decision under risk. Econometrica 1979, 47, 263-292. [CrossRef]

29. Ball, R.; Brown, P. An empirical evaluation of accounting income numbers. J. Account. Res. 1968, 6, $159-178$. [CrossRef]

30. Kormendi, R.; Lipe, R. Earnings innovations, earnings persistence and stock returns. J. Bus. 1987, 60, $323-345$. [CrossRef]

31. Easton, P.D.; Zmijewski, M.E. Cross-sectional variation in the stock market response to accounting earnings announcement. J. Account. Econ. 1989, 11, 117-141. [CrossRef]

32. Collins, D.W.; Kothari, S.P. An analysis of inter-temporal and cross-sectional determinants of earnings response coefficients. J. Account. Econ. 1989, 11, 143-181. [CrossRef]

33. Imhoff, E.; Lobo, G. The effect of ex ante earnings uncertainty on earnings response coefficients. Account. Rev. 1992, 67, 427-439.

34. Basu, S. The conservatism principle and the asymmetric timeliness of earnings. J. Account. Econ. 1997, 24, 3-37. [CrossRef]

35. Mian, G.M.; Sankaraguruswamy, S. Investor sentiment and stock market response to earnings news. Account. Rev. 2012, 87, 1357-1384. [CrossRef] 
36. Dhaliwal, D.S.; Lee, K.J.; Fargher, N.L. The association between unexpected earnings and abnormal security returns in the presence of financial leverage. Cont. Account. Res. 1991, 8, 20-41. [CrossRef]

37. Gow, I.; Ormazabal, G.; Taylor, D. Correcting for cross-sectional and time-series dependence in accounting research. Account. Rev. 2010, 85, 483-512. [CrossRef] 